DUNAMIS (Jurnal Teologi dan Pendidikan Kristiani)

Volume 2, Nomor 1 (Oktober 2017)

ISSN 2541-3937 (print), 2541-3945 (online)

http://www.sttintheos.ac.id/e-journal/index.php/dunamis

\begin{tabular}{|l|l|l|} 
Submitted: 13 September 2017 & Accepted: 10 Oktober 2017 & Published: 31 Oktober 2017
\end{tabular}

\title{
Penderitaan Kristus Sebagai Wujud Solidaritas Allah Kepada Manusia
}

\author{
Sonny Eli Zaluchu \\ Pascasarjana Sekolah Tinggi Teologi Baptis Semarang \\ gloryofgodmin@gmail.com
}

\begin{abstract}
This article is a contemporary theology study about an idea of suffering God. Although there were some notion of suffering God in the church history, yet this remain important to be reconstructed today's in considering the suffering of believers nowadays. This article is a literature research using methodology with qualitative approach, considered developing phenomenons surrounded churches, and analyzed it with biblical reflection of an idea of God's suffered. As the conclusion, with biblical and theological phenomenon analysing, the suffered of Christ must be understood from a big God's plan upon human being.
\end{abstract}

Keywords: Christ's suffering; God; human; solidarity

\begin{abstract}
Abstrak
Tulisan ini merupakan sebuah kajian Teologi Kontemporer tentang ide Allah yang menderita. Walaupun ada banyak pendapat atau pemikiran teologis tentang Allah yang menderita di sepanjang sejarah gereja, namun ide ini tetap penting untuk dikaji kembali pada masa kini, dengan mempertimbangkan konteks penderitaan orang percaya di masa kini. Penelitian ini merupakan literasi dengan menggunakan metode pendekatan yang bersifat kualitatif, mempertimbangkan fenomena yang berkembang di sekitar gereja, dan menganalisisnya dengan pendekatan refleksi biblikal atas ide Allah yang menderita tersebut. Pada akhirnya, melalui analisis biblikal dan fenomena teologis, maka penderitaan Kristus harus dipahami dari sebuah rancangan Allah yang besar atas manusia.
\end{abstract}

Kata kunci: Allah; manusia; penderitaan Kristus; solidaritas Allah 


\section{PENDAHULUAN}

Topik penderitaan Kristus adalah kajian berbad-abad yang tidak pernah selesai. Masing-masing teologi menyusun argumen dengan pendekatan yang berbeda-beda. Ada yang menolak konsep ini karena memegang prinsip impunitas Kristus dan terdapat juga pandangan bahwa impasibiliti adalah satu sisi lain dari wajah Allah yang menderita. Impasibiliti adalah pandangan yang mengatakan Alalh adalah pribadi yang independen yang tidak bergantung kepada manusia atau mahkluk lain. Pandangan ini juga menekankan bahwa Allah tidaklah menderita dan atau merasakan kesakitan karena keberadaan-Nya berada di luar realm manusia dan penderitaan.

Pandangan ini bertahan cukup lama di kalangan teolog abad pertama terutama yang menganut pemisahan antara kemanusiaan Yesus dan keilahiannya. Dennis Ngien menolak anggapan itu. Konsep dan filsafat Yunani menurutnya,

\footnotetext{
${ }^{1}$ Impasibiliti Allah salah satunya berakar dari pandangan filsafat Yunani. Philo, seorang teolog Yahudi Helenistik, beranggapan bahwa Allah tidak memiliki emosi sehingga Ia dapat tertekan. Ide yang sama diadopsi oleh hampir semua bapa gereja awal. Tuhan yang emosional dianggap menganggu ketenangan-Nya sendiri. Konsili Chalcedon yang diselenggarakan tahun 451 SM menyatakan bahwa gagasan Allah yang menderita adalah kesia-siaan, bahkan mengutuk orang Kristen yang menganut paham tersebut. Kematian Yesus di kayu salib dipahami bukan sebagai penderitaan ilahi melainkan penderitaan dari sifat manusia yang ada di dalam diri-Nya. Konsili itu sendiri dikenal merumuskan Kristologi Yesus sebagai manusia ilahi yang utuh dengan dua natur yakni manusiawi dan ilahi (divine).
}

tidaklah tepat dan cocok di dalam menjelaskan konsep penderitaan dan rasa sakit di dalam Alkitab. Kemanusiaan Yesus dan keilahiannya adalah satu dan tidak terpisah. Dennis mengutip Kitamori bahwa Allah menderita rasa sakit karena hubungan-Nya yang telah rusak dengan Israel. Rasa sakit di dalam diri Allah adalah mencerminkan kehendak-Nya untuk mencintai obyek kemurkaan-Nya." Murka Allah bukanlah sifat kemarahan seperti di dalam diri anak-anak, juga bukan sebuah cinta karena frustrasi atau dendam. Sebaliknya, itu adalah ungkapan cinta murni yang tidak memungkinkan Allah berdiri diam saja menghadapi kejahatan manusia. Sifat sejati Allah adalah kasih yang aktif; murka adalah "pekerjaan asing" (strange work) Allah, yang menentang apa pun yang berdiri di antara Dia dengan umat-Nya. 2 Pandangan Dennis ini memunculkan satu argumentasi bahwa jika penderitaan dan rasa sakit adalah satu ekspresi emosional dari Allah yang tidak ada di dalam dirinya, maka bukankah manusia menerima pandangan bahwa Allah adalah kasih dan mencintai ciptaan-Nya, itu juga ada sebuah ekspresi emosi dari Allah? Dengan kata lain, jika kita mengaku bahwa Allah memiliki emosi dengan mencintai manusia maka di saat yang sama Dia juga

\footnotetext{
${ }^{2}$ Dennis Ngien, "The God Who Suffers," Christianity Today, n.d.
} 
memiliki emosi untuk menderita akibat dosa-dosa dan kejahatan manusia itu. Dengan menerima paham impasibiliti maka itu ibarat menolak penderitaan salib sebagai perwujudan kasih Allah kepada manusia. Mengutip Dennis, jika penderitaan Tuhan ditolak, maka artinya salib dievakuasi dari keilahian Kristus. $^{3}$

Dalam bukunya berjudul Yesus dari Nazareth, Paus Benediktus XVI memaparkan bahwa Yesus sebagai anak Allah juga menyebut dirinya sebagai Putra Manusia. Dalam kapasitas-Nya sebagai Putra Manusia, Yesus mengindentifikasi diri memiliki rasa lapar, haus, orang asing, telanjang, sakit, terpenjara dan semua jenis penderitaan di dunia ini. Kenyataan tersebut menjadi suatu bukti teologis bahwa Dia memiliki sikap emosional seperti manusia dalam wujud konkret terekstrem. ${ }^{4}$ Maka ketika Dia dikatakan menderita, realitas itu memang benar-benar terjadi dan bagian tak terpisahkan dari keilahiannya selama berada di bumi.

\section{Apakah penderitaan Salib itu?}

Penderitaan Kristus di Salib adalah sebuah pusat dari penyataan Allah tentang diri-Nya kepada manusia. Bahkan teolog reformasi, Martin Luther, mengatakan, salib haruslah menjadi dasar dan pusat dari

\footnotetext{
${ }^{3}$ Ibid.

${ }^{4}$ Joseph Ratzinger, Yesus Dari Nazareth (Jakarta: PT Gramedia Pustaka Utama, 2010), 346347.
}

seluruh teologi Kristen yang sejati. Luther menyebutkan itu dengan istilah Teologi Salib (Theology of the Cross). Baginya, salib adalah kunci metodologis terhadap keseluruhan teologi. Luther mengatakan, di salib Allah tidak dinyatakan dalam kuasa dan kemuliaan melainkan dalam keilahian yang sangat bertolak belakang, yaitu dalam hal yang diangap aib oleh manusia, kemiskinan, penderitaan dan kematian, dalam apa yang tampak bagi kita sebagai kebodohan dan kelemahan. ${ }^{5}$ Berdasarkan pandangan Luther ini, terlihat bahwa Salib bukanlah pilihan yang menyenangkan karena menekankan aspek penderitaan, tetapi justru karena salib itulah, sebuah Kristologi Kristen yang sejati lahir. Salib, yang penuh penderitaan itu, adalah sebuah pernyataan Allah tentang kasih-Nya yang sejati.

Penderitaan atau sengsara Kristus berasal dari kata passion (Inggris) atau patio (Latin). Artinya, Kristus menderita atau menanggung penderitaan. Hal ini terjadi dalam sebuah rangkaian peristiwa, yang disebut sebagai masa sengsara Yesus, sejak masuk kota Yerusalem hingga kebangkitan-Nya dari kematian. Peristiwa ini sendiri sebagaimana disebutkan pada bagian sebelumnya sudah dirancang di dalam kekekalan. Catatan di dalam Injil

\footnotetext{
${ }^{5}$ Sinclair B. Fergusson, David F. Wright, and J.I. Packer, New Dictionary of Theology (Surabaya: Literatur SAAT, 2008), 257-258.
} 
Sinoptik mengindikasikan ada sekitar 20 sd 30 persen narasinya memberi porsi pada penderitaan Kristus dan kisah sengsaraNya. Bahkan Yesus sendiri telah menubuatkan kisah sengsara itu sebelumnya, sehingga ketika diungkapkan di bagian akhir Injil, pembaca mengenali ini sebagai penggenapan dari apa yang telah diantisipasi sebelumnya.

Dalam surat-surat Perjanjian Baru (PB) lainnya, Pauluslah yang bicara paling banyak tentang salib dan penderitaan yang ada dibaliknya. Paulus menyebut soal salib berulang kali, seperti dalam 1Korintus 1718; Galatia 5:11; 6:12,14; Efesus 2:16; Filipi 2:8, 3:18, Kolose 1:20, 2:14. Paulus juga dicatat sebagai penulis surat-surat PB yang sering berbicara tentang kematian Kristus. Morris menyimpulkan bahwa Salib merupakan pusat injil Kristen sebagaimana dipahami oleh Paulus. ${ }^{6}$

\section{METODOLOGI}

Metode dalam penelitian ini adalah analisis dengan pendekatan kualitatif. Analisis yang dilakukan berupa analisis biblikal tentang ide Allah yang menderita dengan menggunakan beberapa teks terkait. Kemudian analisis dilakukan untuk merefleksikan dengan penderitaan orang percaya zaman sekarang. Pendekatan literatur digunakan untuk melihat beberapa pandangan tokoh yang melihat keterkaitan penderitaan Kristus dengan orang percaya di masa kini. Dengan mempertimbangkan beberapa pandangan teologi kontemporer tersebut dan refleksi Alkitab, maka diperoleh simpulan untuk dijadikan refleksi orang percaya masa kini berkaitan dengan penderitaan yang mereka alami.

\section{ANALISIS DAN HASIL PEMBAHASAN}

\section{Dosa sebagai titik awal}

Seluruh eposide kehidupan Kristus jika ditinjau di dalam kerangka Teologi Penderitaan secara keseluruhan merupakan penderitaan. Salib adalah puncak dari penderitaan tersebut. Pandangan ini beranjak dari kerangka teologis yang disusun Kitamori bahwa penderitaan Allah berjalan paralel dengan kasihNya kepada manusia. Hal itu menampilkan sisi wajah Allah yang terhubung kepada ciptaanNya. Dosa manusia menyebabkan Allah menderita di dalam kasih-Nya dan kemurahan-Nya. Maka dalam rangka itu, Allah membuat God's Grand Design dan salib adalah puncaknya. Gambar di bawah ini memperlihatkan God's Grand Design tersebut. Ini merupakan gambartan awal dari skenario penderitaan Kristus di atas salib.

\footnotetext{
${ }^{6}$ Leon Morris, Teologi Perjanjian Baru (Malang: Gandum Mas, 2006), 89.
} 


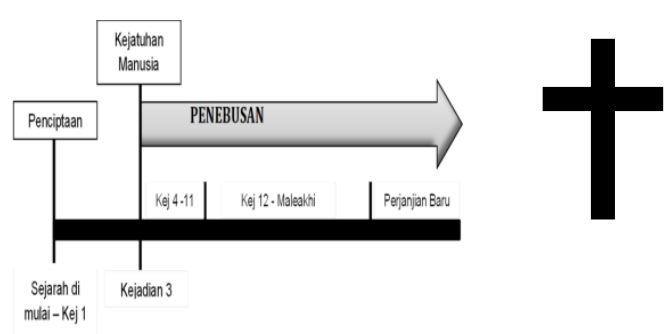

Dosa berakar di dalam tabiat manusia dan menjadi ciri kehidupannya. Sejak kejatuhan, dosa telah menjadi juru mudi kehidupan manusia. Kemana pun manusia pergi, dosa akan berusaha memengaruhi cara manusia mencapai tujuan hidupnya. Dosa selalu mengakibatkan pemisahan dari Allah, dan berarti segala sesuatu yang dilakukan manusia tudak akan dapat diterima atau dihargai Allah sebagai usaha untuk memperoleh keselamatan. ${ }^{7}$

Akibatnya terjadilah penentangan vertikal terhadap Allah dan konflik horizontal dengan sesama. Manusia mendaulat dirinya di atas segala-galanya. Manusia terpisah dari Allah dan tertawan oleh dirinya sendiri. Inilah yang disebut dengan penderitaan akibat dosa yang ditegaskan dalam Yesaya 59:2. Manusia menjadi menderita karena terpisah dengan Allah karena dosa. Agustinus mengatakan bahwa dosa itu merupakan representasi kesombongan manusia. Dosa adalah akibat dari kesombongan, dari suatu tindakan yang di dalamnya suatu makhluk-yaitu suatu makhluk yang pada hakikatnya bersifat

${ }^{7}$ Charles C. Ryrie, Teologi Dasar 2 (Yogyakarta: Penerbit ANDI, 1991), 21. dependen, yang prinsip keberadaannya tidak terletak di dalam dirinya melainkan di dalam diri pribadi lainnya-berusaha untuk berdiri sendiri, untuk mengada bagi dirinya. Berdasarkan kenyataan tersebut di atas, maka bagian paling ujung dari rencana besar Allah atas dunia ini, Tuhan menghadirkan anak-Nya di atas salib sebagai jalan keselamatan. Penderitaan manusia karena dosa, ditebus dengan penderitaan Kristus! Rencana penebusan itu adalah bagian dari usaha Allah memperdamaikan diri-Nya dengan orang berdosa. ${ }^{8}$ Manusia harus mati karena dosa. Tetapi Kristuslah yang menanggungnya.

\section{Salib sebagai ujung Penebusan}

Perjanjian Baru (selanjutnya PB) adalah catatan teknis pelaksanaan penebusan sedangkan Perjanjian Lama (selanjutnya PL) adalah rencananya. Meskipun ini tidak dapat dipisahkan, kesatuan PL dan PB dalam mempersiapkan Yesus menuju Salib disebutkan sebagai God's Grand Design. Kematian Yesus adalah sebuah penebusan dosa. ${ }^{9}$ Kendati hanya melibatkan satu pribadi, yakni Yesus Kristus, tetapi sifat penebusan itu bersifat universal, dunia dan seisinya. Penekanan Petrus yang mengatakan, Ia sendiri telah memikul dosa

\footnotetext{
${ }^{8}$ Darrow L. Miller, Membangun Bangsa Dengan Pikiran Allah (Jakarta: YPPM, 2000), 188.

${ }^{9}$ George Eldon Ladd, Teologi Perjanjian Baru Jilid 1 (Bandung: Yayasan Kalam Hidup, 2002), 248.
} 65 Copyright@ 2017, DUNAMIS, ISSN 2541-3937 (print), 2541-3945 (online) 
kita di dalam tubuh-Nya di kayu salib, supaya kita, yang telah mati terhadap dosa, hidup untuk kebenaran. Oleh bilur-bilurNya kamu telah sembuh (1 Pet. 2:24) adalah sebuah jawaban yang sangat deskriptif. Memikul dosa adalah sebuah ungkapan yang menjelaskan keadaan seseorang yang menderita konsekuensi atas dosa dan menanggung hukumannya. ${ }^{10}$

Kesaksian PB mendukung akan hal tersebut. Konsep ini ditemukan dalam perkataan Yesus dan dihampir semua tulisan PB. Yesus mengajar bahwa tidak ada orang yang dapat memberikan sesuatu apapun sebagai ganti nyawanya Markus menulis, karena apakah yang dapat diberikannya sebagai ganti nyawanya? (Mark. 8:37). Bandingkan dengan Mazmur yang mengatakan, Tidak seorangpun dapat membebaskan dirinya, atau memberikan tebusan kepada Allah ganti nyawanya, karena terlalu mahal harga pembebasan nyawanya, dan tidak memadai untuk selama-lamanya-- supaya ia tetap hidup untuk seterusnya, dan tidak melihat lobang kubur. (Mzm. 49:7-9) Tetapi bahwa Anak Manusia datang untuk memberikan nyawanya sebagai tebusan bagi banyak orang seperti dikatakan dalam Markus, "Karena Anak Manusia juga datang bukan untuk dilayani, melainkan untuk melayani

\footnotetext{
${ }^{10}$ John Stott, Allah - Dosa - Anda (Jakarta: Metanoia, 2009), 134.
}

dan untuk memberikan nyawa-Nya menjadi tebusan bagi banyak orang." (Mark 10:45; 1 Tim 2:6; Tit. 2:14). Konsep tersebut mengarah pada satu kesimpulan bahwa kematian Yesus di atas salib dipahami sebagai pengorbanan nyawa untuk rencana keselamatan manusia. Dan, pengorbanan nyawa, adalah sebuah penderitaan bagi yang mengalaminya. (Rom. 3:24; 1 Pet. 1:18). Allah mampu melakukan rencana itu dan dengan inisiatifnya sendiri memilih untuk mengorbankan anak satu-satu-Nya sebagai tebusan bagi banyak orang. ${ }^{11}$ Ia memutuskan melakukan sesuatu yang bagi kita tidak mampu melakukannya sendiri. ${ }^{12}$ Salib adalah bagian terpenting dari misi Mesias dalam konteks sejarah penebusan.

Surat-surat Rasul Paulus, menurut Morris, adalah usaha untuk memperlihatkan bahwa kematian Yesus itu ada kaitannya dengan kematian yang seharusnya dialami oleh orang-orang berdosa. Mereka seharusnya mati karena kematian adalah "upah dosa." (Rom. 6:23). Paulus berkata, Sebab kasih Kristus yang menguasai kami, karena kami telah mengerti, bahwa jika satu orang sudah mati untuk semua orang, maka

\footnotetext{
${ }^{11}$ Inisiatif Allah bersifat final; sekali untuk selamanya. Kata Yunani yang dipakai adalah hapax dan turunannya, ephapax. Biasanya hapax diterjemahkan sebagai tindakan satu kali dan untuk selama-lamanya, berlaku baik dalam pewahyuan maupun penebusan.

${ }^{12}$ John Stott, No Title Christ The Controversialist - Meneladani Pelayanan Dan Pengajaran Yesus Yang Radikal (Surabaya: Literatur Perkatnas, 2014), 103
} 
mereka semua sudah mati. (2 Kor 5:14). Tidak mudah memahami maksudnya, kecuali bahwa Kristus telah menjalani kematian yang seharusnya dialami oleh orang-orang berdosa. ${ }^{13}$ Sungguh luar biasa memahami jalan berpikir Paulus tersebut. Satu nyawa Kristus yang mati bagi manusia telah menebus seluruh nyawa manusia yang seharusnya mati.

\section{Sejarah Salib}

Penyaliban mungkin pertama kali diperkenalkan oleh orang-orang Persia. Alexander Agung kemudian memperkenalkan bentuk hukuman itu di Mesir dan Kartago. Roma mengadopsi hukuman mengerikan itu dari orang-orang Kartago. Meskipun Roma bukan pencipta metoda ini, mereka telah menyempurnakan bentuk penyiksaan dan hukuman mati yang dirancang dengan sengaja untuk menghasilkan kematian yang lambat dengan rasa nyeri maksimum dan penuh penderitaan. Ini adalah salah satu metode eksekusi yang yang paling memalukan bagi orang dan keturunan yang mengalaminya sekaligus terkejam yang hanya diperuntukkan bagi budak, orang asing, pemberontak, penjahat dan pelaku kriminal berat. ${ }^{14}$ Mengingat beratnya penderitaan di salib, hukum Romawi bahkan menetapkan

\footnotetext{
${ }^{13}$ Morris, Teologi Perjanjian Baru, 89.

${ }^{14}$ John Stott, Kristus Yang Tiada Tara (Surabaya: Penerbit Momentum, 2013), 17
}

seperti apapun kejahatan yang dilakukan warganya, mereka dilindungi untuk tidak dihukum mati lewat salib, kecuali untuk satu perkara, yaitu berlaku bagi serdadu yang desersi. Pengalaman ini menimbulkan sebuah refleksi bagi kekristenan, mengutip Stott, jika kita mau mengikut Kristus dan memikul salib, hanya ada satu tempat yang bisa kita datangi, dan itu adalah tempat hukuman mati. ${ }^{15}$

Dalam bentuk paling awal di Persia, korban diikat pada sebuah pohon atau dipakukan di sebuah tiang yang tegak, dengan kaki tetap bisa menyentuh tanah. Kemudian metode hukuman ini berkembang dengan menggantung sepenuhnya terhukum di sebuah salib yang besar dengan palang di bagian atas. Bentuk palang ini kemudian bervariasi di banyak lokasi penyaliban dan sesuai dengan imajinasi para algojo. Dalam kasus penyaliban Yesus, Dia berjalan telanjang dada sambil memukul palang seberat 136 kg. Prosesi ke tempat penyaliban dipimpin oleh seorang penjaga militer lengkap Romawi, dipimpin oleh seorang centurion. Salah satu prajurit membawa tanda (titulus) yang mencatat nama si terhukum dan kejahatan yang diperbuatnya. Kemudian, titulus itu akan dipakukan di bagian atas salib. Penjaga tidak akan meninggalkan

\footnotetext{
${ }^{15}$ Ibid.
} 67 Copyright@ 2017, DUNAMIS, ISSN 2541-3937 (print), 2541-3945 (online) 
korban sampai mereka yakin terhukum sudah mati.

\section{Salib: Cara Mati Mengerikan}

Salib tidak muncul begitu saja dalam skenario Tuhan. Salib dipilih karena cara mati melalui salib adalah kematian yang lambat dan sangat membawa penderitaan bagi orang yang mengalaminya. Setidaknya inilah yang menjadi kesan di dalam Injil Markus, bahwa Yesus adalah hamba yang menderita karena salib, yang mati bagi dosa-dosa umat-Nya. ${ }^{16}$ Kitab Markus, menurut Stott, adalah kitab Injil yang memaparkan penderitaan salib di hampir sepertiga isinya. ${ }^{17}$ Salah satunya dituliskan: Kemudian mulailah Yesus mengajarkan kepada mereka, bahwa Anak Manusia harus menanggung banyak penderitaan dan ditolak oleh tua-tua, imamimam kepala dan ahli-ahli Taurat, lalu dibunuh dan bangkit sesudah tiga hari (Mark. 8:31). Di nats itu ada frasa 'menanggung banyak penderitaan' yang merujuk pada totalitas penderitaan Yesus menuju salib bagi banyak orang. Totalitas itu salah satunya terlihat dari cara Yesus menjelaskan diri-Nya sebagai 'anak manusia' sebuah ungkapan posisi terendah dan terdalam sebagai hamba-Nya. ${ }^{18}$

\footnotetext{
${ }^{16}$ Ibid, 13.

${ }^{17}$ Ibid, 15 .

${ }^{18}$ Oscar Cullman, Christology of the New Testament (SCM Press, 1963), 60.
}

\section{Tubuh yang Dipakukan}

Di luar tembok kota terletak secara permanen tiang kayu yang berat, di mana palang yang dibawah terhukum akan disatukan. Setiba di lokasi eksekusi, korban diberi minuman anggur pahit bercampur mur (empedu) sebagai analgesik ringan. Terhukum kemudian dilemparkan ke tanah dengan punggung menghadap tanah, dan tangan terentang sepanjang palang. Tangan lalu diikat atau dipaku. Tentara romawi biasanya senang menggunakan paku. ${ }^{19}$ Setelah kedua lengan telah dipakukan ke palang, korban diangkat ke tiang pancang. Bila tiang pancangnya tinggi, tentara mengangkat terhukum dengan garpu kayu dan memakukan palang itu ke tiang yang tegak tersebut. Bagian selanjutnya adalah mengikat atau memaku kaki. ${ }^{20}$ Setelah itu penderitaan panjang dimulai hingga ajal menjemput terhukum.

Apabila tentara tidak mau menunggu berlama-lama, maka kadang mereka mempercepat kematian terhukum dengan memukul tungkai kedua kaki terhukum saat tersalib hingga patah dan atau menusuk lambungnya hingga masuk ke paru-paru

\footnotetext{
${ }^{19}$ Sisa-sisa arkeologi dari tubuh yang disalibkan, telah ditemukan di sebuah osuarium dekat Yerusalem dan berasal dari zaman Kristus, menunjukkan bahwa terdapat sisa paku yang melekat di tulang antara telapak dengan pergelangan sepanjang 13 sampai $18 \mathrm{~cm}$.

${ }^{20}$ Temuan osuarium dan Kain Kafan Turin menunjukkan bahwa memaku kaki adalah praktik yang disukai tentara Romawi.
} 
dengan tombak dari arah bawah. Tubuh Yesus yang dipakukan di atas kayu Salib, oleh Collins disebut sebagai deskripsi puncak penderitaan Kristus sebagai sebuah pengorbanan untuk penebusan dosa dan tindakan kasih kepada manusia. ${ }^{21}$

\section{Penderitaan Fisik Yesus}

Salib sebagai bentuk hukuman mati perlahan-lahan yang sangat menyiksa membawa dampak secara fisik pada terhukumnya. Dan memang, itulah maksud penyaliban, agar fisik terhukum mengalami siksaan panjang dan kesakitan yang tiada tara. Bagaimana menggambarkannya?

Taman Getsemani merupakan permulaan. Pergumulan Yesus yang berat membuat pembuluh darah halus di bawah kulit pecah dan bercampur dengan keringat akibat tekanan mental dan penderitaan jiwa yang sangat hebat. Peluhnya berubah menjadi darah. Kemudian Dia sendirian di dalam tekanan itu. Pengkhianat datang dengan ciuman di taman Getsemani dan Yesus ditangkap. Semua murid meninggalkan Dia. Yesus dibawa kepada Kayafas untuk diadili. Di sana berulangulang memperolok, meludahi dan manampar Dia. Juga dibawa bolak-balik ke bagian lain dari wilayah Jerusalem untuk diperiksa oleh Pilatus. Pengadilan palsu

\footnotetext{
${ }^{21}$ Gerald O'Collins, Christology - A Biblical, Historical and Systematic Study of Jesus (Oxford: Oxford University, 2009), 306.
}

menjadi panggung tempat Yesus berdiri. Di depan mata-Nya, rakyat yang semula mengelukan Hosana ! berbalik menolaknya dan meminta-Nya dihukum untuk disalibkan. Mereka berteriak, salibkan Dia! ${ }^{22}$ Dalam perjalanan memikul salib, mahkota duri dipasangkan di atas kepalaNya. Mahkota ini dibuat dari sejenis tanaman di Palestina yang getahnya beracun sehingga ketika menusuk kulit, bukan hanya sakit karena seluruh kepalaNya ditusuk kuat-kuat oleh duri-duri itu, tetapi racun dari tanaman ini menjalar ke dalam luka dan menimbulkan kesakitan yang kuat.

Setelah semua proses itu selesai, Yesus memasuki tahap pencambukan di markas tentara Romawi. Melalui cara ini, fisik menjadi lemah dan terhukum kehilangan tenaga yang besar. Arkeologi membuktikan bahwa cambuk Romawi tidak hanya berupa utas tali tetapi memiliki gotri tajam seperti pisau-pisau kecil di ujungnya seperti rumbai-rumbai tajam sehingga saat menerima pukulan, daging terhukum teriris dengan kuat bahkan dagingnya dapat tercongkel saat cambuk ditarik. Secara medis, terhukum mengalami trauma pada tubuhnya karena deraan dan pengeluaran darah. Tekanan darah dapat menurun

\footnotetext{
${ }^{22}$ Robert R. Boehlke, Siapakah Yesus Sebenarnya (Jakarta: BPK Gunung Mulia, 2001), 85-92.
} 69 Copyright@ 2017, DUNAMIS, ISSN 2541-3937 (print), 2541-3945 (online) 
drastis seiring dengan hilangnya cairan tubuh. Semua syaraf menegang menahan sakit. Di tengah penderitaan itu, Yesus harus memikul salibnya menuju Golgota.

Palang itu berat sehingga beberapa kali Yesus terjatuh di Via Dolorosa karena tidak kuat menanggungnya. Setiba di Golgota, Yesus direbahkan di tanah untuk dipakukan di palang, luka-luka bekas cambukan dipunggungnya akan pasti akan terkoyak kembali, berdarah terkena benturan tanah. Kepedihan luka yang dirasakan semakin bertambah-tambah. Dalam tahap ini, terhukum dapat kehilangan kesadaran dan mengalami demam.

Kedua pergelangan tangan kemudian direntangkan tetapi tidak tegang, dan kedua kaki, dengan posisi tidak lurus tetapi tertekuk, dipaku ke palang salib. Paku-paku di kedua pergelangan tangan akan merobak otot, daging dan urat syaraf motorik karena saat digantung, tubuh akan tertarik ke bawah dan kedua paku di pergelangan tangan itu menjadi satu-satunya penahan berat badan. Yesus dapat mengalami kelumpuhan di atas salib. Rasa sakit ini menjalar ke seluruh persendian, sementara di saat yang sama, kedua kaki menjadi satusatunya tumpuan berat tubuh, tidak mampu menopang karena kehilangan tenaga akibat penyiksaan sebelumnya. Orang yang disalib biasanya mengalami penyempitan di kedua paru-parunya sehingga susah bernafas dan setiap kali tarikan nafas terjadi, berat badan menumpuk ke bawah sehingga tubuh yang ditahan oleh kedua paku di lengan menjadi lebih berat. Itu artinya otot dan daging menjadi robek lagi karena tubuh seperti ditarik ke bawah. Maka jalannya udara lewat paru-paru menjadi lemah dan pendekpendek. Jika terhukum mendorong tubuh ke atas, paku di kedua kakinya akan mendatangkan kengerian yang hebat di seluruh tubuh. Sementara di saat yang sama, tulang kaki menjadi tumpuan seluruh tubuh.

Seluruh episode itu bukanlah rekaan tetapi kejadian nyata. Penderitaan yang dialami Yesus tidak terlukiskan. Itu sebabnya Dia berteriak, Kira-kira jam tiga berserulah Yesus dengan suara nyaring: "Eli, Eli, lama sabakhtani?" Artinya: Allah$\mathrm{Ku}, \quad$ Allah- $\mathrm{Ku}$, mengapa Engkau meninggalkan Aku? (Mat. 27:46). Seruan itu adalah seruan puncak dari titik kesakitan Yesus. Sesaat kemudian, Ia berkata dengan lemah, "Sudah selesai." Lalu Ia menundukkan kepala-Nya dan menyerahkan nyawa-Nya. (Yoh. 19:30).

Jadi, mengapa Yesus menderita dan berada di dalam kengerian penderitaan seperti digambarkan di atas? Apakah ini semata-mata selalu dijawab klasik sebagai hasil dosa manusia dan realisasi rencana Allah dalam penebusan? Apakah ada 
makna lain yang lebih relevan dari sekadar persoalan klasik di atas?

\section{Solidaritas Allah}

Solidaritas Allah kepada manusia, adalah sebuah cara pandang baru dalam menjelaskan penderitaan Yesus. Paulus, misalnya, memberikan gambaran tentang penderitaan ilahi di dalam penebusan dalam suratnya kepada jemaat di Roma. Di dalam Roma 8:18-30, Paulus mengindikasikan bahwa "penderitaan zaman sekarang ini" disuarakan melalui "keluhan" ciptaan dan anak-anak Allah.

Paulus menulis, sebab kita tahu, bahwa sampai sekarang segala makhluk samasama mengeluh dan sama-sama merasa sakit bersalin. Dan bukan hanya mereka saja, tetapi kita yang telah menerima karunia sulung Roh, kita juga mengeluh dalam hati kita sambil menantikan pengangkatan sebagai anak, yaitu pembebasan tubuh kita (Rom. 8:22-23). Dan Allah melalui Roh-Nya bergabung di dalam ratapan penderitaan manusia sebagai ciptaan, sehingga Roh itu "berdoa untuk kita kepada Allah dengan keluhan-keluhan yang tidak terucapkan" (Rom. 8:26). Ini adalah salah satu ungkapan solidaritas yang dimaksud. Allah tidak membiarkan manusia menderita sendirian. Dengan bentuk solidaritas ini juga, manusia dalam segala aspek penderitaannya di muka bumi, mendapat kekuatan dan pengharapan ${ }^{23}$, bahwa Allah telah lebih dahulu merasakan penderitaan yang lebih berat melalui kematian anak-Nya. Penderitaan yang berpuncak di dalam diri Yesus merupakan kisah tentang Allah yang menanggungkan penderitaan dunia kepada dirinya sendiri. ${ }^{24}$

\section{Kedaulatan Allah}

Penderitaan adalah representasi kedaulatan Allah. Kedaulatan Allah adalah ajaran Alkitab bahwa segala sesuatu berada di bawah kekuasaan dan kendali Tuhan, dan tidak ada yang terjadi tanpa arah atau izinNya. Tuhan bekerja bukan hanya beberapa hal tetapi segala sesuatu sesuai dengan kehendak-Nya sendiri, termasuk penderitaan. Seperti apa pun penyebab penderitaan menimbulkan rasa sakit fisik dan emosional pada manusia, semua itu tidak akan pernah melebihi kadaulatan Allah. John Piper merumuskan dalam beberapa pandangan yang lebih spesifik. Dalam bukunya Penderitaan dan Kedaulatan Allah, Piper mengatakan bahwa salib merupakan sebuah pameran kemuliaan anugerah Tuhan dalam

\footnotetext{
${ }^{23}$ Harls Evan Siahaan, "Mengajarkan Nasionalisme Lewat Momentum Perayaan Paskah: Refleksi Kritis Keluaran 12:1-51," DUNAMIS (Jurnal Teologi dan Pendidikan Kristiani) 1, no. 2 (2017): 39-54, www.sttintheos.ac.id/ejournal/index.php/dunamis.

${ }^{24}$ Leland Ryken, James C. Wilhoit, and Tremper Longman III, Kamus Gambaran Alkitab (Surabaya: Penerbit Momentum, 2011), 241.
} 
pencapaian Kristus dengan penderitaan-Nya tersebut. $^{25}$

Pertama, Kristus menyerap murka Allah atas nama manusia - dan Ia melakukannya di dalam penderitaan. Murka Allah yang mestinya menyebabkan penderitaan kekal bagi manusia telah jatuh kepada Kristus. Ini adalah kemuliaan anugerah, dan hanya dapat datang melalui penderitaan. Dalam surat kepada jemaat di Galatia dituliskan Kristus telah menebus kita dari kutuk hukum Taurat dengan jalan menjadi kutuk karena kita, sebab ada tertulis: "Terkutuklah orang yang digantung pada kayu salib!" (Galatia 3:13)

Kedua, Kristus menanggung dosa-dosa kita dan membeli pengampunan kita-Ia melakukannya dengan penderitaan. Dosadosa yang seharusnya menghancurkan kita di bawah beratnya rasa bersalah telah dialihkan kepada Kristus. Ini adalah kemuliaan anugerah dan hanya dapat datang melalui penderitaan. Hal itu ditegaskan di dalam surat rasul Petrus yang mengatakan, Ia sendiri telah memikul dosa kita di dalam tubuh-Nya di kayu salib, supaya kita, yang telah mati terhadap dosa, hidup untuk kebenaran. Oleh bilur-bilurNya kamu telah sembuh (1 Pet. 2:24).

Ketiga, Kristus menyediakan kebenaran yang sempurna untuk kita yang menjadi

\footnotetext{
${ }^{25}$ John Piper, Penderitaan Dan Kedaulatan Allah (Surabaya: Penerbit Momentum, 2012), 94-96.
}

milik kita di dalam Dia; dan Ia melakukannya dengan penderitaan. Ketaatan Kristus yang dengannya banyak orang diperhitungkan sebagai orang benar haruslah merupakan suatu ketaatan sampai mati, bahkan sampai mati di kayu salib. Ini adalah kemuliaan anugerah dan hanya dapat datang melalui penderitaan. Di dalam Filipi dikatakan, melainkan telah mengosongkan diri-Nya sendiri, dan mengambil rupa seorang hamba, dan menjadi sama dengan manusia. Dan dalam keadaan sebagai manusia, Ia telah merendahkan diri-Nya dan taat sampai mati, bahkan sampai mati di kayu salib (Fil. 2:7-8).

Keempat, Kristus mengalahkan mautIa melakukannya dengan penderitaan. Sengat maut ialah dosa dan kuasa dosa ialah hukum Taurat. Tetapi kemenangan kita atas dosa diperoleh melalui Yesus Kristus melalui penderitaan-Nya. Ibrani mengatakan, karena anak-anak itu adalah anak-anak dari darah dan daging, maka Ia juga menjadi sama dengan mereka dan mendapat bagian dalam keadaan mereka, supaya oleh kematian-Nya Ia memusnahkan dia, yaitu Iblis, yang berkuasa atas maut; dan supaya dengan jalan demikian Ia membebaskan mereka yang seumur hidupnya berada dalam perhambaan oleh karena takutnya kepada maut (Ibr. 2:14-15). 
Kelima, Kristus melucuti iblis — dan Ia melakukannya di dalam penderitaan. Ketika catatan mengenai pelanggaran-pelanggaran kita dipaku di atas Salib dan dibatalkan, maka kukasa iblis untuk menghancurkan kita pun telah dibatalkan. Senjata telah dirampas dari tangan iblis di atas salib. Di dalam Kolose dikatakan, dengan menghapuskan surat hutang, yang oleh ketentuan-ketentuan hukum mendakwa dan mengancam kita. Dan itu ditiadakan-Nya dengan memakukannya pada kayu salib: Ia telah melucuti pemerintah-pemerintah dan penguasa-penguasa dan menjadikan mereka tontonan umum dalam kemenangan-Nya atas mereka (Kol. 2:14-15).

Keenam, Kristus membeli penyembuhan akhir yang sempurna untuk semua umatNya-Ia melakukannya dengan penderitaan. Dikatakan di dalam Yesaya, Ia dihina dan dihindari orang, seorang yang penuh kesengsaraan dan yang biasa menderita kesakitan; ia sangat dihina, sehingga orang menutup mukanya terhadap dia dan bagi kitapun dia tidak masuk hitungan. Tetapi sesungguhnya, penyakit kitalah yang ditanggungnya, dan kesengsaraan kita yang dipikulnya, padahal kita mengira dia kena tulah, dipukul dan ditindas Allah. Tetapi dia tertikam oleh karena pemberontakan kita, dia diremukkan oleh karena kejahatan kita; ganjaran yang mendatangkan keselamatan bagi kita ditimpakan kepadanya, dan oleh bilurbilurnya kita menjadi sembuh (Yes. 53:3-5)

Ketujuh, Akhirnya, Kristus membawa kita kepada Allah-dan Ia melakukannya di dalam penderitaan. Pencapaian tertinggi dari salib bukanlah kebebasan dari sakit penyakit, melainkan persekutuan kembali kepada Allah seperti tertulis dalam surat Petus, Sebab juga Kristus telah mati sekali untuk segala dosa kita, Ia yang benar untuk orang-orang yang tidak benar, supaya Ia membawa kita kepada Allah (1 Pet. 3:18).

\section{KESIMPULAN}

Dari semua uraian di atas dapat dipahami bahwa jalan penderitaan yang dipilih Yesus adalah unik. Karena hal itu dilakukan dalam sebuah rangkaian rencana yang telah disusun di dalam kekekalan (God's Grand Design). Penderitaan, kematian dan kebangkitan-Nya merupakan satu paket tindakan Allah yang meneguhkan pencapaian Yesus melalui kematian-Nya. Penderitaan-Nya unik karena Dia melebihi manusia biasa dalam melakukan jalan salib, karena di dalam dirinya berlaku dua hakikat sekaligus; manusia seratus persen dan Allah seratus persen. Manusia biasa tidak akan kuat menanggung penderitaan yang sama. Tetapi Yesus mampu dan kuat. Dia tidak bersalah dalam penderitaan itu. Dia mengatakan alasannya, Bapa mengasihi Aku, oleh karena Aku memberikan nyawa-Ku untuk 
menerimanya kembali. Tidak seorangpun mengambilnya dari pada-Ku, melainkan Aku memberikannya menurut kehendak-Ku sendiri. Aku berkuasa memberikannya dan berkuasa mengambilnya kembali. Inilah tugas yang Kuterima dari Bapa-Ku (Yoh. 10:17-18).

Dari semua rangkaian penderitaan tersebut, perdebatan mengenai siapa sebetulnya yang membunuh Yesus bukanlah yang terutama. Dia memilih menderita dan mati. Bapa-Nya telah menetapkannya. Dia menaati-Nya ! John Piper mengatakan dalam bukunya The Passion of Jesus Christ, ada lima puluh alasan biblikal mengapa Yesus datang untuk mati. Dan sebagai konklusinya, semua penderitaan itu adalah rancangan Allah. Kita tidak perlu mempertanyakan alasannya. Allah merancangnya untuk kebaikan seluruh dunia.

\section{DAFTAR PUSTAKA}

Boehlke, Robert R. Siapakah Yesus Sebenarnya. Jakarta: BPK Gunung Mulia, 2001.

Cullman, Oscar. Christology of the New Testament. SCM Press, 1963.

Fergusson, Sinclair B., David F. Wright, and J.I. Packer. New Dictionary of Theology. Surabaya: Literatur SAAT, 2008.

Ladd, George Eldon. Teologi Perjanjian Baru Jilid 1. Bandung: Yayasan Kalam Hidup, 2002.

Miller, Darrow L. Membangun Bangsa Dengan Pikiran Allah. Jakarta: YPPM, 2000.
Morris, Leon. Teologi Perjanjian Baru. Malang: Gandum Mas, 2006.

Ngien, Dennis. "The God Who Suffers." Christianity Today, n.d.

O'Collins, Gerald. Christology - A Biblical, Historical and Systematic Study of Jesus. Oxford: Oxford University, 2009.

Piper, John. Penderitaan Dan Kedaulatan Allah. Surabaya: Penerbit Momentum, 2012.

Ratzinger, Joseph. Yesus Dari Nazareth. Jakarta: PT Gramedia Pustaka Utama, 2010.

Ryken, Leland, James C. Wilhoit, and Tremper Longman III. Kamus Gambaran Alkitab. Surabaya: Penerbit Momentum, 2011.

Ryrie, Charles C. Teologi Dasar 2. Yogyakarta: Penerbit ANDI, 1991.

Siahaan, Harls Evan. "Mengajarkan Nasionalisme Lewat Momentum Perayaan Paskah: Refleksi Kritis Keluaran 12:1-51." DUNAMIS (Jurnal Teologi dan Pendidikan Kristiani) 1, no. 2 (2017): 39-54. www.sttintheos.ac.id/ejournal/index.php/dunamis.

Stott, John. Allah - Dosa - Anda. Jakarta: Metanoia, 2009. - Kristus Yang Tiada Tara. Surabaya: Penerbit Momentum, 2013. - No Title Christ The Controversialist-Meneladani Pelayanan Dan Pengajaran Yesus Yang Radikal. Surabaya: Literatur Perkatnas, 2014. 